\section{8. 測定器の信頼性について}

北里大 医療機器センター

野村智之池田光喜 稲毛博留生伸一 大広和明楠宣世 西川 温廣瀬稔 本多隆

北里大 麻酔科

渡辺敏

現在臨床の場で使用されている多くの医療機器の安 全性は日本 $M E$ 学会の医用電気機器安全基準により維 持されているが，これらの機器の機能，精度などを検 定するために市販されている各種測定器の安全性・信 頼性は確保されているであろうか.

今回われわれは測定器の信頼性に疑問を抱かせるよ うな事例を経験したので報告すると同時にこの点に関 して問題提起をしたい.問題の測定器は電気メスの出 力を測定するもので, 当施設所有の測定器での測定結 果とメ一カ所有の同機種の測定器のそれとの間に大き な差が生じ，電気メスの保守点検業務に支障を来し現 在その原因を究明中である.

各種測定器を用いて多くの医療機器の安全性・信頼 性を維持している時に,このような事態が起こること 非常に困るため何らかの方法でこれら測定器の信頼性 を向上するための対策をたてる必要があると思われる。

\section{9. コンピュータによる医療機器の管理}

\section{北里大 医療機器センター}

廣瀬稔池田光喜 稻毛 博 爪生伸一 大広和明楠 宣世 野村智之西川温 本多隆 北里大 麻酔科 渡辺敏

北里大学病院における医療機器センターの発足およ び業務内容などは昨年度の本学会にて紹介した. 医療 機器 (現在73機種約1500台) 貸出しなどの業務や臨床 データ管理を手作策により行ってきたが，年々増加す る機器管理台数とそれにともなう機器貸出し業務や各
種データ管理などの業務の向上のため, 昭和58年 9 月 よりコンピュータを導入した. コンピュータは北里大 学病院総合情報システム (KTIS) の IBM 4341 で, その端末機を用いて機器の管理を行ってきている.

今回過去 5 力月間の使用により機器管理, 特に在庫 および貸出し状沉などの把握や一定期閒の統計資料の 作成時などには非常に便利である反面，KTIS の端末 機を使用しているため優先順位が低く各診療科からの 機器請求に対し機器貸出しまでの時間がかかるなどの 欠点がわかった・これらの欠点および今後予想される 問題点などについて報告する。

\section{0. 北里大学病院中央手術部における医療機 器の保守, 管理の現状について}

北里大 中央手術部
中條武美 中村 晃
江原 博 中村俊夫
松林 光 鈴木好信
根 本 谱
北里大 医療機器七ンター・麻醉科
渡 辺 敏
北里大麻酔科
中田 中 亮

北里大学病院中央手術部では，14の手術室において 年間約5200件の手術が行われている. その手術に使用 される医療機器の数は非常に多く，ポリグラフなどの モニタ類も増加の一途をたどっている. 多くの手術を 支障なく安全に遂行させるためにはこれらの機器の保 守点検, 整備は事故発生の防止上重要といえる.

当中央手術部の14名の医療技術員はこの目的のため 次のよらな業務を行っている.

1. 電気メスの保守, 管理

1. 麻酔器および麻酔器具の点検, 整備

1. 人工呼吸器, 超音波ネブライザの点検

1. ポリグラフの保守, 管理および操作

1. 心拍出量計の管理および心拍出量の測定

1. ベッドサイドモニタの整備

1. 手術台, 無影灯, 顕微鏡の作動点検

1. クラニオトーム, エアトームのドリル類の点検, 整倩

以上により，開院以来13年になるが医療機器に関す る大きな事故はなく，また医療機器の故障によって手 術の進行がさまたげられたこともない。

医療技術員による中央手術部の医療機器の保守点検, 
整倩の利点としては，次のようなことが挙げられる. まず第 1 は医療機器を常に最もよい状態で安全に使用 できる点である．また簡単な故障の修理は医療技術貴 が行えるのでメーカに依賴をしなくても済む。さらに 故障個所の把握が適格にできるのでメーカへの修理依 頼時に連絡が密にききる．また看護婦，医師などにメ 一カに代わっていっでも機器の取り扱い説明ができる. 整備がいきとどくので機器の耐久性がのびるなどの良 い点が挙げられる。

今後の課題としては，医療技術員の専門的知識の蓄 積が必要であり, 医療機器センターと連携, また当院 としての各種医療機器の取り扱い手順書の作成などが ある。

\section{1. 医療機器の安全性向上について 機器購入時の検討}

\author{
北里大 医療機器センター・麻酔科 \\ 渡辺敏 \\ 北里大 事務部施設課 \\ 茞田正美 \\ 北里大 事務部経理資材課 \\ 高 橋修
}

医用電気機器は J I S T 1001に基づき製造され， それらが使用される設備は J I S の病院電気設備安全 基準で管理され, 機器の安全性が維持されているが, 実際にこれらの機器を購入した際には, 機器の重量, 使用電気容量，電圧および医療配管，上下水道設備な どとの関係において，いろいろと問題が生じることが あるため注意する必要がある。

北里大学病院ではこのような問題を事前に解決する ため，昭和56年から独自のシステムを採用しこのよう な問題に対処しているため報告する．このシステムで は機器購入申請時にその機器に関する仕様書を提出さ せ，それをもとに重量，電気容量，電圧，医療配管な どに関して安全性の面から専門の委員会で審議し，そ の機器の購入の是否を決定する時に参考にすることに している．過去 3 年間で問題となった事例をあげ，そ れに対してとった対策について報告する.

\section{2. 手術室 $M E$ 機器使用上の工夫}

東京医歯大 手術部

池内宏 長谷清一 古橋正吉 東京医歯大 麻酔科 沢桓

ここ数年来, 手術室における $\mathrm{ME}$ 機器の利用度の増 加は著しいものがある.そしてME機器自体の主性能 はI C化やマイコンの利用などによって確かに向上し ているが, その反面, 付属品をも含めた機器全体とし ての使いやすさの点では依然として問題が多い。しか しながらその責任を機器設計上の問題として一方的に メーカ側に押しつけても問題が解決するわけではない。 というのは一般的にいって, 器械というものは実際に 使ってみてはじめてどこがどのように具合が悪いかと いうことが判ってくるものだからである。

本報告においては，一見ささいに見えることかもし れないが，手術室で実際にME機器を使ってみた上で なされたいくつかの使用上の工夫について発表したい。 というのは，こ机らの工夫によって私共自身が，日帖 $\mathrm{ME}$ 機器を使っていく上で少なからぬ便利さを味わっ ているからであり，これをご紹介して，ME機器を使 用していく上でのヒントにしていただければ幸いと孝 えるからである。

その内容は下記のようなものである。

(1) コードやホース類をつるすバンド

(2) 接地用金具つき $3 \mathrm{P}$ テーブルタップ

(3) $3 \mathrm{P}$ テーブルタップの機器への取り付け

(4) 使用上のポイント説明書の機器への貼付

(5) 輸液ポンプのシリンジ先のガード

（6）心電図八ム防止のためのアルミテープによる電線 の簡易シールド

（7）電気毛布による心電図ハム防止用のアルミシート 